\title{
8 \\ Wellbeing Perspectives, Conceptualisations of Work and Labour Mobility Experiences of Pasifika Trans-Tasman Migrants in Brisbane
}

\author{
Ruth (Lute) Faleolo
}

\begin{abstract}
Mo'ui 'oku lelei ... the way I see it, as I compare it to [New Zealand] our quality of life as a family is affected by our income. Our income here is good with only my husband working ... You know what makes a 'good and happy life'? It is when a person makes a decision to take a chance. When I go and look for my life goals and I achieve it; this is what makes my life good because I made the move to go and look for it. (Interview/Talanoa with Safaia, 16 July 2015)
\end{abstract}

Pasifika trans-Tasman migrations include processes of labour mobility that reflect Pasifika agency in the pursuit of wellbeing. This chapter draws on the preliminary findings of wider ongoing research that has examined the wellbeing of Pasifika trans-Tasman migrants moving from New Zealand to Australia. The narratives of Samoan and Tongan trans-Tasman migrants reveal a holistic, Pasifika notion of wellbeing that influences migrants' decision-making in relation to migration and employment. This notion, articulated in Samoan as ola manuia and in Tongan as mo 'ui 'oku

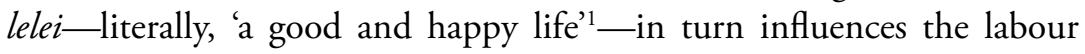

1 Faleolo, 'Pasifika Trans-Tasman Migrant Perspectives'. 
mobility experiences of Pasifika trans-Tasman migrants, including their negotiations of immigration and social security policies, and sometimes restrictive regulatory regimes.

The term 'Pasifika' denotes a pan-Pacific Islander collective identity. It is used by many Pacific Islanders themselves, including the Samoan and Tongan trans-Tasman migrant groups whose experiences are the focus of this chapter. An increasing number of Pasifika migrants, particularly New Zealand-born Pasifika, are moving from New Zealand to settle long-term in Australia. ${ }^{3}$ While much existing research has emphasised the political-economic factors underlying this migration, including higher wages and accessible standards of living in Australia, ${ }^{4}$ little research has been conducted into the thoughts and experiences of trans-Tasman Pasifika migrants themselves. We can gain insight into trans-Tasman Pasifika labour mobility, and better understand the motivations and experiences of these migrants, ${ }^{5}$ by hearing their migration narratives and accurately capturing their voices as Pasifika migrants. ${ }^{6}$ The wellbeing perspectives of Pasifika trans-Tasman migrants influence their decisions on where and how they will participate in the labour market, whether in New Zealand or Australia. The narratives documented in this discussion reveal the advantages and disadvantages experienced in Auckland ${ }^{7}$ and Brisbane ${ }^{8}$ that have encouraged the relocation of Pasifika to Australia since the 1990s. More importantly, this discussion delves into the most recent (often unrecorded) experiences of labour mobility in Australia, highlighting Pasifika narratives and voices to contribute to an indigenous account of Pasifika labour mobility.

In exploring this intersection of regulatory regimes and Pasifika conceptualisations of wellbeing, this chapter draws on 40 interviews carried out in 2015-17 with Samoan and Tongan communities in both Brisbane and Auckland. The research is informed by my own positions

2 McGavin, 'Being Nesian'; Mila-Schaaf, 'Polycultural Capital'.

3 Both Bedford and Ravulo detail the growing trend of New Zealanders, particularly New Zealand-born Pasifika, moving to Australia. Bedford, 'Pasifika Migration'; Ravulo, Pacific Communities in Australia.

4 For example, Brown and Walker, Migrants and their Remittances; Hamer, "'Unsophisticated and Unsuited"'; Ho, Hugo and Bedford, 'Trans-Tasman Migration in Context'.

5 Hamer acknowledges that there is an evident silence in the diaspora literature of Pasifika migrant voices about their migration from New Zealand to Australia. Hamer, "Unsophisticated and Unsuited"'.

6 Smith, Decolonizing Methodologies.

7 Salesa, 'Damon Salesa: Our Pacific'.

8 Ravulo, Pacific Communities. 
as a Tongan researcher who is married to a Samoan. Importantly, my inquiry and participant-observation work have embraced both a Samoan and Tongan framework of cultural knowledge and protocols, taubi $v \bar{a}^{9}$ and teu le $v \bar{a},{ }^{10}$ both of which are important in nurturing and maintaining mutually respectful relationships and spaces, or $v \bar{a}$, within Pasifika contexts. ${ }^{11}$ In upholding $v \bar{a}$ in my research practice, I have used a culturally responsive interviewing methodology based on the Tongan concept of talanoa ${ }^{12}$ - that is, a reciprocal 'two-way' interviewing process. Talanoa is a 'conversation, a talk, an exchange of ideas or thinking, whether formal or informal ... and interacting without a rigid framework. ${ }^{13}$ It is promoted by Pasifika scholars as a way of opening up dialogue about traditional values and in-depth understanding that is within the hearts and minds of Pasifika. ${ }^{14}$ Standfield and Stevens, in this volume, promote the importance of indigenous methodology based on conversational narratives that illuminate the connected migration histories between New Zealand and Australia. The traditional method of face-to-face talanoa was supplemented in this research by a novel use of online forums for talanoa, which I term e-talanoa. The development of this method was in direct response to the request of Pasifika informants' ${ }^{15}$ to communicate via online forums. As a method, e-talanoa is more suited to contemporary ways of communicating (i.e. by email or Facebook private messenger); it gave informants more time to contemplate their responses to questions and was also responsive to the pressures of time experienced by many of these Pasifika migrants. The discussion that follows focuses predominantly on the experiences of Pasifika migrants in Brisbane, but also draws on relevant material from Auckland-based interviews, as the relationship between the two sites casts particular light on trans-Tasman labour mobility.

9 Kàili, Marking Indigeneity, 31-33; Mahina, 'Tā, Vā, and Moana', 169.

10 Anae, 'Teu Le Va', 222.

11 Developing good relations with Pasifika rests on $v \bar{a}$, a reciprocal relationship that upholds the moral, ethical, spiritual dimensions of social relationships as Pasifika. Anae, 'Teu Le Va', 222-23. The term $v \bar{a}$ is used by both Samoan and Tongan groups.

12 Talanoa has been widely accepted as a qualitative approach within several Pasifika Melanesian and Polynesian academic circles. Fa'avae, Jones and Manu'atu, 'Talanoa'i 'a e Talanoa'; Halapua, 'TalanoaTalking from the Heart'; Latu, Talanoa: A Contribution; Otsuka, Talanoa Research; Prescott, 'Using Talanoa'; Vaioleti, 'Talanoa Research Methodology'; Vaka’uta, 'Tālanga: Theorizing a Tongan Mode'.

13 Vaioleti, 'Talanoa Research Methodology', 16.

14 Havea, Talanoa Ripples; Latu, Talanoa: A Contribution.

15 Faleolo, 'Pasifika Trans-Tasman Migrant Perspectives'. 
In focusing on the lived experiences, wellbeing perspectives and motivations of Pasifika labour migrants, this account also contributes to important 'indigenous narratives of decolonisation' ${ }^{16}$ by detailing Pasifika migrants' own narratives of the limitations and regulations that they have experienced living in Australia, particularly since the 1990s, as well as their own agency and meaning-making in the context of their transnational lives.

\section{Holistic Wellbeing-Mo‘ui ‘Oku Lelei- Ola Manuia}

In narrating their migration experiences, Pasifika trans-Tasman migrants articulated understandings of 'wellbeing' that went beyond tangible outcomes or improvements in the life of an individual. ${ }^{17}$ The Tongan concept moiui 'oku lelei and Samoan concept ola manuia ('a good and happy life') embrace many dimensions of life that are integral to how Pasifika people live on a daily basis. Pasifika trans-Tasman migrants defined wellbeing beyond just a state of physical or emotional health, including important familial and spiritual dimensions. Other Pasifika studies have found a similar holistic notion of wellbeing. ${ }^{18}$

Sione, ${ }^{19}$ a 38-year-old, second-generation Pasifika migrant of Tongan descent ${ }^{20}$ was based in Perth at the time of our initial e-talanoa. By the time of a follow-up, face-to-face talanoa a year later, Sione had successfully migrated to Brisbane after purchasing a family home in Ipswich. Although Sione continued to fly out to the mines for work, he had plans to leave this form of employment in exchange for a family business that would build on his existing community networks across Tonga, Auckland, Sydney, Perth and Brisbane. He explained his understanding of mo ui 'oku lelei:

16 Banivanua Mar, Decolonisation and the Pacific, 179; See also Sailiata, 'The Samoan Cause'.

17 Faleolo, 'Pasifika Trans-Tasman Migrant Perspectives'; Faleolo, 'Understanding Pasifika Migrant Behaviour'.

18 Manuela and Sibley, 'The Pacific Identity'; Meo-Sewabu and Walsh-Tapiata, 'Global Declaration'.

19 Pseudonyms are used for all interviewees/informants mentioned in this discussion.

20 First-generation Pasifika migrants were either born in Samoa or Tonga prior to migrating. Second-generation Pasifika migrants were born to first-generation Pasifika migrants in either Australia or New Zealand, and third-generation Pasifika migrants were born to second-generation Pasifika migrant parents in either New Zealand or Australia. 
Being physically and mentally healthy ... being able to have quality time and being content with [a] lifestyle that is healthy ... happy with family life. Spending time with my family. Staying true to God and my family. Being able to spend my time doing what really matters to me. To be around to meet my grandchildren and to be able to retire from working full-time before I turn 50 .

'Ina, a 35-year-old Samoan, second-generation migrant, had moved to Brisbane from Auckland in 2015 after receiving spiritual confirmation that it was the right time for her to leave the sales industry and take up a new career in social work. She shared her understanding of ola manuia:

Having the simple necessities in life to at least be comfortable. Healthy family relationships, being well connected to family. Being physically healthy, able to still do physical activity to feel good and eating well. Being spiritually healthy too, having that intimate relationship with God. Mentally stable too, which I guess ties in with the other three. If one area is lacking, it can affect the others.

These two narratives reveal the holistic notions of wellbeing valued by all the Pasifika migrants interviewed in the study. Particularly significant are the familial and spiritual spheres. For instance, the underlying motivation for Sione's decision to move to Brisbane was for his children to grow up in close proximity to his sister's family who was already living in Brisbane at the time. 'Ina's decision to move to Brisbane from Auckland was inspired by her faith in God and a belief that she was 'called' by God to change her location and career. She believed that this trans-Tasman migration would help to strengthen her relationship with God as well as her relationships with others, especially family. References to spiritual and familial influences recurred throughout the 40 migration narratives captured in the study.

\section{Importance of Familial Wellbeing in Pasifika Decision-Making}

Both Gershon and Lilomaiava-Doktor highlight the importance of Pasifika familial connections in the process of migration. ${ }^{21}$ When making decisions to live and work in Brisbane, Pasifika prioritise their familial sphere of wellbeing-fämili (Tongan) and äiga (Samoan).

21 Gershon, 'Viewing Diasporas from the Pacific'; Lilomaiava-Doktor, 'Beyond "Migration”'. 
The progress of fämili and 'aiga are important considerations that sit at the core of Pasifika trans-Tasman migrants' decisions to transfer between employment opportunities in Auckland to Brisbane. These anticipated mobility 'benefits' exceed the temporal, emotional, financial or cultural 'costs' of leaving family members and familiar ways of life that are in New Zealand. ${ }^{22}$ Within Pasifika conceptualisations of wellbeing, aims such as 'getting better pay' or securing 'better job opportunities', although seemingly individualistic wellbeing aims for migration, are conceived primarily as means of providing for and maintaining 'familial' connections or $v \bar{a}$ (good, positive and strong relationships within Pasifika families). Within Pasifika conceptualisations and lives, familial connections and obligations extend far beyond nuclear families; for many, they also extend across expansive transnational spaces.

'Alisi, a 48-year-old Tongan woman and first-generation trans-Tasman migrant to Brisbane, had just started up a family-run courier franchise at the time of her talanoa. She was also studying part-time towards a business diploma. 'Alisi shared her desire to maintain fämili wellbeing in Brisbane:

We moved here because I wanted to be closer to my parents who live in Inala [a Brisbane suburb], and the lifestyle here is better for my children ... plus, when I go to send money to my [extended] family back in Tonga, the exchange rate is better here than in New Zealand.

Sharing her hopes for an improved moui oku lelei for herself and her family, 'Alisi continued:

My goal is to carry on with my education here in Brisbane. I believe that a better education will help me to reach my goals for a good life here with my family ... I've been in the factory all my life, and I have to struggle with it ... when I reach a higher education, I will achieve higher goals, because the higher I go, the better it will be for my family and a happy life for us, mo ui 'oku lelei ... yeah, I've been working in the factory all my life, but when I get to a level 3 certificate in my business studies, I can get a better job, so I know that if I keep on studying I will get a better job. 


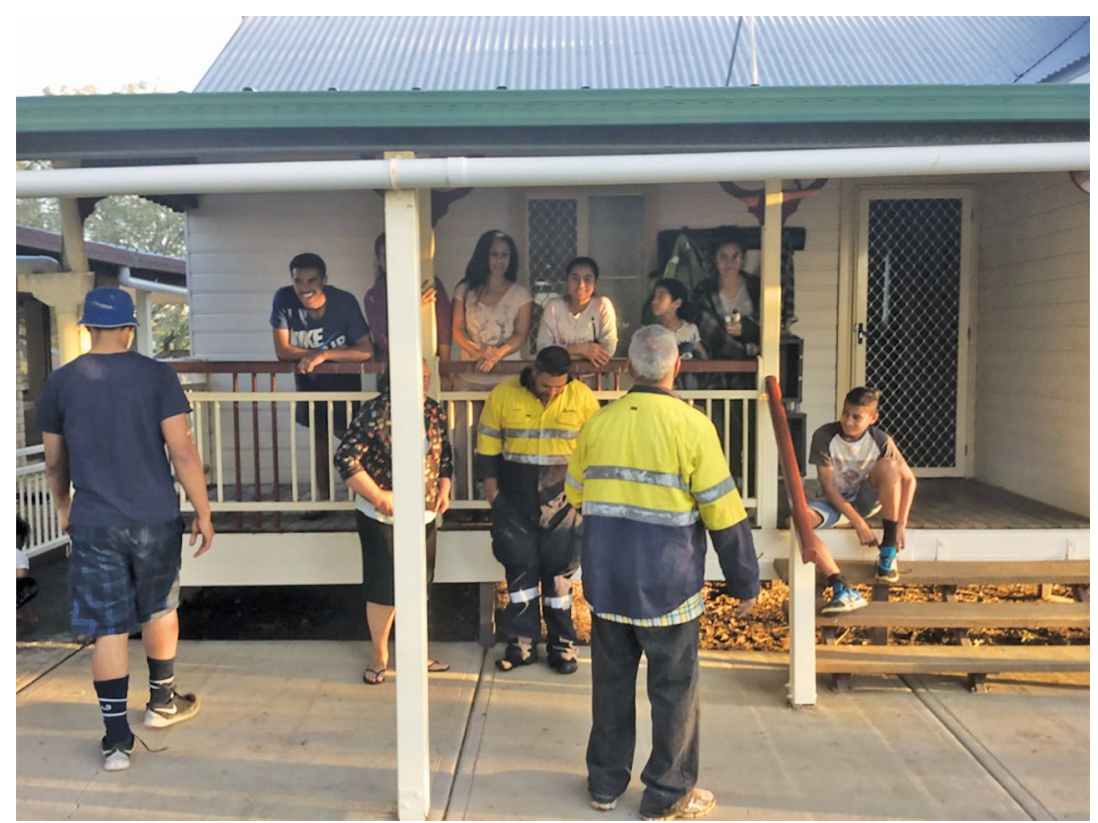

Figure 8.1: A Brisbane-based Tongan/Māori family relaxing after work on their rural property, 2016.

Source: Photograph by Ruth (Lute) Faleolo.

Sinamoni, a Tongan, second-generation trans-Tasman migrant, had migrated from New Zealand in 2011 to develop her career and to pursue a higher education degree. Now 31 years old, she described her and her husband's experiences of an improved mo'ui 'oku lelei in Brisbane:

I like my life here in Brisbane, I wanted to be in Brisbane for education and work experience because it is a great stepping stone to the global places like America ... I like that you can make out of life what you want here in Brisbane, it's like a blank piece of paper, it's a freedom that I get being in a place of opportunities, just make what you want of it. Money is good here, better than in Auckland $\ldots$ and there is a greater margin of savings here ... I think that people are more fulfilled here because they've come here and they are being creative. It makes me and my husband feel alive to set financial goals, achieve them and then plan the next goal, it builds our self-esteem as a family. There is a faith we have here in this country that 'you can do it', we have a greater chance of achieving our goals here as a family. 


\section{Pasifika in Australia}

Pasifika migration across the Tasman Sea from New Zealand to Australia, and particularly to Brisbane, is part of a general trans-Tasman migration flow of New Zealanders. There has been a consistent increase in this flow since the late 1960s, due mainly to the two countries' close proximity, as well as their cultural connections. ${ }^{23}$ Pasifika trans-Tasman migration is also often facilitated by the preferential migration access accorded to New Zealanders under Australia's migration policy; this is particularly so for those Pasifika who are born in New Zealand and, thus, have New Zealand citizenship or permanent residency rights, or who otherwise obtain these rights because of New Zealand's visa and citizenship regimes that accord rights to people from many Pacific Island nations on the basis of New Zealand's colonial history in the region (something, incidentally, that Australia does not do). Green, Power and Jang explain that New Zealanders sometimes become permanent migrants 'by default' when they continue living in Australia after a temporary move. ${ }^{24}$ This is often the case for New Zealand-born Pasifika, or Pasifika who have obtained New Zealand citizenship, who often become permanent migrants after travelling to Australia to visit family.

Since the mid-1990s, the number of New Zealand-born Pasifika arriving in Australia has exceeded the arrival numbers of Pasifika born in the Pacific Islands. ${ }^{25}$ Currently, Queensland is home to the largest cluster of Pasifika in Australia, with more than 102,000 Pasifika living there, particularly in Brisbane. ${ }^{26}$ As a New Zealand documentary series, Tagata Pasifika, described it in 2015, Australia has become the new 'land of milk and honey' for New Zealand Pasifika seeking improved lifestyles. ${ }^{27}$ Indeed, since the 1960s, migration flows between Australia and New Zealand have moved strongly in Australia's favour, with relative economic conditions between the two countries being the main cause of high net migration loss to Australia. ${ }^{28}$ There has also been a broadening of Australia's immigration

\footnotetext{
23 Green, Power and Jang, 'Trans-Tasman Migration', 34; Poot, 'Trans-Tasman Migration'.

24 Green, Power and Jang, 'Trans-Tasman Migration', 35.

25 Based on Australian census figures available for 2011, Hamer reported that New Zealandborn Samoans outnumbered those born in Samoa for each year of arrival since 1995. Similarly, New Zealand-born Tongans outnumbered those born in Tonga. Hamer, "'Unsophisticated and Unsuited"', 113.

26 Ravulo, Pacific Communities, 4.

27 Tagata Pasifika. Second Migration.

28 Haig, New Zealand Department of Labour Report.
} 
policies since the mid-1970s that allowed for new groups of migrants arriving from all parts of the world to enter Australia. However, the usual migration procedures that other migrants have to comply with do not always apply to New Zealand citizens under the trans-Tasman agreement that exists between the two nations. This freedom of entry, together with New Zealand and Australia's close proximity and the strong pull of employment opportunities, encourages New Zealand-born Pasifika and those with New Zealand citizenship to live and work in Australia. Although the increase of Pasifika arriving in Australia has been recorded as a migration trend occurring since the 1990s, this contemporary transTasman migration by Pasifika forms part of a centuries-old tradition of Pasifika migrating away from their homelands, in search of new opportunities and resources. ${ }^{29}$

\section{Wellbeing Possibilities and Regulated Inequalities for Pasifika Trans-Tasman Migrants}

Since the 1920s, the Australian and New Zealand governments have had arrangements in place that have allowed their citizens ease of movement between the two countries; Australian and New Zealand citizens are allowed to migrate between Australia and New Zealand without the need to obtain visas, and have the ability to live and work within these two countries without qualifying on skills-based or humanitarian grounds. ${ }^{30}$ The 1973 Trans-Tasman Travel Arrangement (TTTA) formalised this long-standing understanding. ${ }^{31}$ As a result of this arrangement, an estimated 640,770 New Zealand citizens were present in Australia by 2013 with work and residence rights. ${ }^{32}$ The preferential migration arrangements that New Zealand have with many Polynesian countries (including Samoa and Tonga) mean that Pasifika with New Zealand citizenship are able to access Australian residence and work opportunities by virtue of the TTTA. A consequence of this is a much higher rate of migration to Australia (and Australian labour market participation) by

29 Banivanua Mar, 'Shadowing Imperial Networks'; Hau'ofa, 'Our Sea of Islands'; Keck and Schieder, 'Contradictions and Complexities'; Mallon, Māhina-Tuai and Salesa, Tangata o le Moana.

30 Green, Power and Jang, 'Trans-Tasman Migration', 35.

31 Walrond, 'Kiwis Overseas'.

32 'Fact Sheet - New Zealanders in Australia', Department of Home Affairs, accessed 14 March 2019, archive.homeaffairs.gov.au/about/corporate/information/fact-sheets/17nz. 
Polynesian people in contrast to Melanesians entering the country via New Zealand. This implication of the TTTA is discussed by Mackay and Guinness in this volume in relation to Fijian migrants who have experienced more difficulty in obtaining residency in either Australia or New Zealand. However, since 1994, policy changes announced by the Australian Government have meant residency status changes and decreased benefits for migrants, including Pasifika, arriving from New Zealand. As of 1 September 1994, all non-citizens in Australia were expected to hold a visa to remain in the country. The Special Category Visa (SCV), introduced for New Zealand citizens as a temporary visa, was automatically issued upon arrival in Australia. It controls the benefits and opportunities received by New Zealand citizens in Australia, such as social welfare assistance, medical benefits and tertiary fees support. These policy changes reveal the ambivalent role that government visa schemes and social welfare policies play in controlling the level of access to socio-economic benefits. ${ }^{33}$ As discussed by Mackay and Guinness in this volume, Australia has gradually withdrawn benefits and rights to New Zealand citizens. This ultimately creates an un-level playing field of challenging social and economic circumstances that contemporary Pasifika trans-Tasman migrants find themselves in on arrival to Brisbane. The recent changes to Centrelink access have created socio-economic differences across the community with benefits changing over time and affecting people's circumstances across several generations.

In 2001, the Australian Government introduced changes to the Social Security Act 1991. After 26 February 2001, a New Zealand citizen arriving for the first time in Australia was classified as a non-protected SCV holder and was required to apply for an Australian permanent visa to access particular social security assistance. In short, this meant that a New Zealander could enter Australia to settle and work, but could not have any benefits or rights as Australian citizens or permanent residents. For example, New Zealand citizens, on turning 18 or after leaving high school, although considered 'domestic' fee-paying students on enrolment to an Australian tertiary institution, are required to pay full fees up-front at the beginning of each semester. They are not eligible for student loans or allowances and do not qualify for Australian scholarships unless they have completed their final year of high school in Australia. Some Pasifika

33 Note: Some Australian Government policies (e.g. 2017 changes to Centrelink children's education bonuses) affect both New Zealand citizens and Australian citizens alike. 
trans-Tasman migrants who want a tertiary qualification will have to choose between returning to New Zealand for a student loan supported degree and entering the Australian workforce as an unskilled or untrained worker. Pasifika migrant narratives highlight the ripple effect of the 2001 policy changes on the level of education and employment opportunities accessible to them and their New Zealand-born children in Brisbane.

'Onika, a 37-year-old, first-generation Tongan woman living in Brisbane, shared during talanoa her experience of paying her New Zealand-born children's university fees up-front at the beginning of each semester. In the face of significant challenges, she had successfully set up a trans-Tasman business in Brisbane and Auckland with the help of her father and siblings in Auckland. This strategy of utilising family connections had enabled her to provide important financial support while her children completed their studies in Brisbane. 'Onika is committed to working long hours, flying constantly between Auckland and Brisbane to build a successful business that will ensure her family's future wellbeing.

During participant observation at a Brisbane-based Pasifika cultural event in 2016, three second-generation New Zealand-born Pasifika youth, all in their early 20s, shared their concerns about being 'stuck in the factory' as picker packers ${ }^{34}$ because they were unable to afford the course fees to attend TAFE or university in Australia. The effects of the 2001 policy changes are part of the coloniality evident in Pasifika experiences of labour mobility (i.e. the engrained way that Australia looks to Pasifika as a source of 'unsophisticated and unsuited' labour ${ }^{35}$ ) whereby policies reinforce colonial labour relations and socio-economic inequality.

\section{Pasifika Wellbeing: Housing, Work and Family in Brisbane}

For a Pasifika worker, the familial sphere of wellbeing is maintained through the act of giving and sharing their work outcomes through their extended, often transnational, family networks. These outcomes (such as resources, time, talents, skills and money) are given by Pasifika to help the

34 The 'picker packer' role in a warehouse or factory usually involves an individual or team of individuals 'picking' up shelved or stored items, as listed in an order sheet, and 'packing' these items ready for despatch and delivery.

35 Hamer, "'Unsophisticated and Unsuited”, 93. 
progress of their family livelihood and wellbeing. Despite the challenges affecting Pasifika trans-Tasman migrants, particularly in relation to access to Australian benefits, Pasifika rated their improved wellbeing experiences more highly in Brisbane compared to Auckland. Pasifika migrants in Brisbane were more satisfied with their ability to provide a better lifestyle and home for their nuclear family, as well as to help their extended family, in comparison to Pasifika satisfaction to do likewise in Auckland. What Auckland provides in family and Pasifika community support cannot be matched in Brisbane. However, what Brisbane provides is the fulfilment of trans-Tasman migration aims for better job opportunities, more money to improve living standards for the family (both nuclear and extended) and a lifestyle that provides more quality time with the family. There is a higher level of Pasifika satisfaction in job security, career prospects, income and home ownership in Brisbane compared to Auckland. An interesting finding in the Brisbane-based interviews with informants who had moved to Brisbane in the last five to 10 years was their ownership of a home. There is greater opportunity for Pasifika to own a home in Brisbane, reflecting the greater margin of savings that is possible in Brisbane as a result of higher incomes and lower living expenses. In most cases, this meant a short time of shared sacrifices-staying with relatives who owned a home and sharing the costs of living to maximise their collective incomes while saving for a home deposit. For these informants, owning a home and having the income to afford this asset, as well as a better lifestyle, has helped them to achieve wellbeing for their whole family, not just themselves. Here, again, family is conceived in expansive and transnational terms. For example, a family home will not only provide accommodation and support for immediate family, but also for extended family members visiting or relocating to Brisbane from New Zealand, Samoa, Tonga or elsewhere. Home ownership thus forms part of the familial support systems $s^{36}$ through which Pasifika enact agency and sustain relationships in the context of regulated inequalities, governmental coercion and socio-economic pressures.

36 Gershon, 'Viewing Diasporas from the Pacific'. 


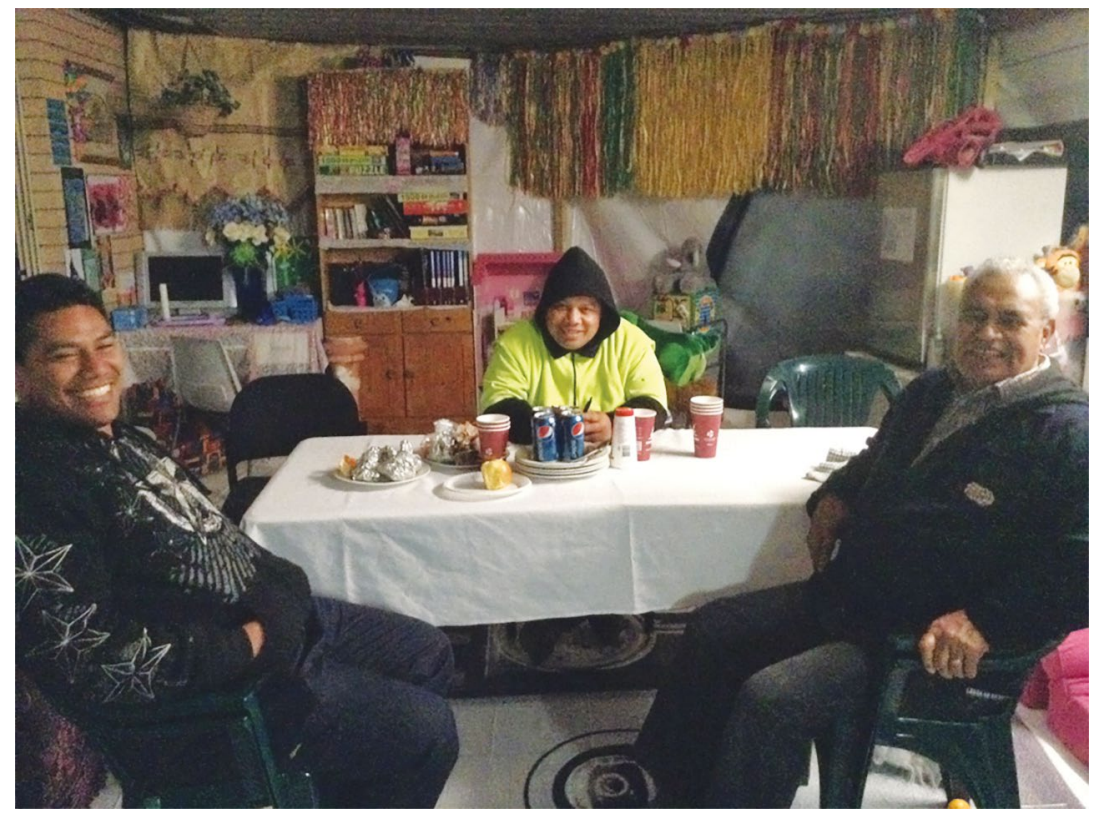

Figure 8.2: A Tongan family home used for weekly Pasifika community meetings in Brisbane, 2015.

Source: Photograph by Ruth (Lute) Faleolo.

'Amelika, a 42-year-old, first-generation migrant from Tonga, shared her story of labour mobility in Auckland and Brisbane. 'Amelika and her husband had each worked two full-time jobs in Auckland just to keep up with their living expenses and mortgage payments. After visiting relatives in Brisbane during 2008 and seeing the possibilities of a better lifestyle for their family, they decided to sell their family home in Auckland and move to Brisbane. In Brisbane, with the support of their extended family and church community, they purchased a better quality home at a more affordable price. 'Amelika set up a family day care centre that allowed her to spend time with her children while working from home. She took advantage of government-funded night courses for family day care educators and inspired other Pasifika women in her networks to do the same. Further, by sharing her family's progressive experiences in Brisbane on her Facebook page, she inspired other family members in Auckland to join them. 
Pasifika understandings of the value of work relate to improved wellbeing. In many ways, this is similar to notions of work within the non-migrant mainstream. ${ }^{37}$ Pasifika understandings of work and wellbeing departs from mainstream notions at the point of motivation. There was general consensus among the Pasifika informants of this study that work and participation in the labour force is, first and foremost, about helping family to progress. According to all 40 narratives, going to work and having a job is something that Pasifika take great pride in because they are able to contribute to the wellbeing of their family, which, in turn, nurtures their individual wellbeing. Dominant notions of work suggest that an individual's participation in labour is mainly driven by the desire for personal gain (i.e. more money to buy goods and services) and more leisure. ${ }^{38}$ When an understanding of Pasifika wellbeing (i.e. holistic progress in all spheres, particularly for the family) is applied to the daily work life of a Pasifika migrant, we begin to understand that the desire for 'work' for Pasifika is not about their individual benefit but, rather, their capacity to share the benefits of their labour with others. Indeed, for some Pasifika trans-Tasman migrants, it has been more important to take up a job based in Brisbane that paid better wages than to stay in higher ranking or more professional occupational roles in Auckland that did not provide the same opportunities for meeting familial obligations.

Pasifika trans-Tasman migrants use these understandings and draw on family networks to mitigate negative experiences of labour mobility in Brisbane. Dialogue with Brisbane-based informants about their experiences of Australia's 2001 policy changes highlighted the importance of Pasifika trans-Tasman support networks that helped to sustain migrants and their families on first arrival to Brisbane from Auckland. Thus, as well as providing accommodation for arriving family, as discussed above, these forms of transnational familial support also extend to employment. It is common practice among Pasifika migrants living in Brisbane to 'hook up a job' or 'put in a good word' for their relatives who are planning to join them. This networking of fämili or áiga is a result of the Pasifika understanding that their employment in a company is not just about their own livelihood but is also, if possible, and where possible, an avenue for them to extend the job opportunity to others.

37 Arenofsky, Work-Life Balance; Gray et al., 'Post-Fordist Reconfigurations of Gender'.

38 Ehrenberg and Smith, Modern Labor Economics; Fleming, Kifle and Kler, 'Immigrant Occupational Mobility'. 
Tavake's story illustrates the significance of this concept of a shared labour mobility. In 2003, Tavake, a trans-Tasman migrant, was being forced to work extra days and for longer hours in his work as a labourer in Auckland. This began to take a toll on his health and it was not long before his relatives in Brisbane heard about his situation. Tavake's cousin in Brisbane helped him to find a job in his workplace and Tavake was able to start there as a labourer in 2004. Although he was doing similar labour-intensive work as he had been in Auckland, he was getting a higher pay rate in Brisbane. A year later, he had saved enough funds to bring his wife and children from Auckland to Brisbane. The following year, Tavake saved enough money from his job to make a deposit on a home for his family in Brisbane. During the talanoa with Tavake's family, they explained how grateful they were for the opportunities they had received through their cousin in 2004. In exchange for his kindness, they were helping another family who had just migrated to Brisbane with provision of a job at Tavake's workplace as well as shared accommodation in their family home.

There is a shared understanding among the informants that the outcome of their labour not only contributes to the wellbeing of their nuclear and extended family, but also to a wider community. Pasifika migrant narratives make reference to this wider community that has provided a support network in Brisbane extending beyond fämili or áiga. For most of the 40 informants, this wider community included church families and local connect groups ${ }^{39}$ that they met with on a regular basis and other local associations (such as their children's sports club, school or work community). These social networks help Pasifika migrants to find their place within diaspora contexts like Brisbane. 'Alisi, the Tongan transTasman migrant running a courier franchise while studying for a business diploma, explained that, apart from providing for her fämili based in Brisbane and in Tonga, she wants 'to be a good citizen in Australia, someone that is useful to her country'. For 'Alisi, building a successful business in Brisbane has a greater purpose of serving the wider community, and this gives her a sense of improved wellbeing. Similarly, La'ei, a 29-year-old Samoan first-generation migrant, shared her hopes of helping struggling youth through her performing arts career in Brisbane.

39 Connect groups (home groups) are based on social connections within the church community that informants belonged to. 
Many other informants shared similar stories of proactively supporting other Pasifika migrants in Australia. Stead, in this volume, describes the supportive role Tongans and Samoans who have lived in Victoria for decades play in facilitating the migration and settlement of other Pasifika. These support systems have been formed through family and church networks and maintained by regular events such as family celebrations, reunions or annual church conferences. According to Pasifika migrant narratives, these networks often span across more than one state (the most frequently mentioned interstate support systems were family and church connections existing across New South Wales and Queensland) and often include New Zealand, their Pacific homelands of Samoa and/or Tonga, and sometimes the United States. Pasifika migrant families who are established in Brisbane often become fundamental support networks for family members planning to migrate from Auckland, and this is an accepted form of contribution to the collective good. Therefore, the Pasifika conceptualisation of work is essentially of a meaningful process through which an individual can produce good outcomes that flow into social progress for the family and community, including their country. These notions of work and wellbeing motivate Pasifika participation in economic opportunities and encourage positive responses to challenges met during their migration to Australia.

However, the labour mobility experiences of Pasifika trans-Tasman migrants are not always positive, and migration to Brisbane does not always yield the improvements to wellbeing that are hoped for. Depending on the date of their migration to, and settlement in, Brisbane, different Pasifika trans-Tasman migrants have varying levels of access to financial assistance. As discussed previously, there are differences in the levels of access to benefits and support based on the date of arrival to Australia from New Zealand. One effect of these different regulations is the inconsistent spread of benefits available to any given family. For example, a family with first-, second- and third-generation migrants will experience differing levels of access to education and, therefore, unequal opportunities to develop their career pathways based on their age cohort, place of birth and citizenship rights as Australians, New Zealanders or Pasifika.

For some families, the disparity caused by social security regulatory changes in Queensland have led to a separation of parents from their children. Australian-born Pasifika children have been left with their Brisbane-based extended family members (acting as legal caregivers) when New Zealand-born Pasifika parents, who have struggled to find 
permanent employment in Brisbane and received no access to social security to support their children, are forced to return to Auckland for work. Loto, a 45-year-old Samoan woman, shared her story of migration from Auckland to Brisbane in 2013 and her return to Auckland in 2014. After several months of struggling to transfer her academic qualifications and skills into meaningful employment in Brisbane, Loto returned to Auckland, leaving her children in Brisbane in the care of her parents. It is an acceptable and common practice among Pasifika extended family networks to share the responsibilities of looking after children when parental support is required. To this extent, Loto's story emphasises the role of extended family as a safety net in the process of Pasifika labour mobility and wellbeing fulfilment. However, it is also the case that Loto experienced great sadness, both in her inability to secure employment, and in her separation from her children.

\section{Shared Labour Mobility, Pasifika Agency and Regulatory Constraint}

The ability to network across the Tasman and remain connected across families (nuclear and extended) through church and wider community support systems is what sustains Pasifika trans-Tasman migrants in Brisbane. In articulating a vision of a good and happy life, the concepts of ola manuia and as mo'ui 'oku lelei facilitate a positive mindset among Pasifika, encouraging them to seek opportunities, including employment and business, through migration. This positive mindset is built on two important outlooks. First, the anticipation of migration and labour mobility benefits for the fämili or 'äiga. Second, a progressive outlook for the flow-on effect of migration and labour mobility on others (the wider community that a migrant strongly identifies with including the church, community, city, region or country). At the same time, the forms of relationship that these concepts engender underpin support networks that better enable Pasifika migrants to migrate and to settle with relative ease in Brisbane. The creation and maintenance of these networks, and the active seeking out of ola manuia and móni 'oku lelei, are forms of restorative Pasifika agency that allow trans-Tasman migrants to negotiate the labour mobility challenges posed by Australian regulatory regimes. Similarly, in this volume, Stead discusses the 'development dreams' that maintain the numbers of Pasifika horticulture workers in Victoria, while Mackay and Guinness discuss the 'economies of hope' that drive Fijian rugby players 
to Australia. These forms of Pasifika agency are fuelled by shared future aspirations and supported by transnational familial connections that also share the sacrifice of labour mobility and migration. The act of giving support to fellow Pasifika trans-Tasman migrants enriches relationships or $v \bar{a}$ between new arrivals, 'áiga or fämili remaining in the homelands, and host Pasifika families that provide support.

In a sense, contemporary Pasifika migrants have contributed (and are contributing) to an ongoing indigenous globalisation ${ }^{40}$ that works to overcome coloniality-reflected here in the ongoing, racialised and hierarchical structures of power that Pasifika migrants encounter in Australia and New Zealand's current labour market-determining their own indigenous mobility outcomes through mobilising culturally rich understandings and values, and strong local and global fämili or 'äiga connections. This indigenous globalisation does not simply negate or ameliorate the effects of colonial histories and ongoing racialised hierarchies, but it does highlight the role and capacity of Pasifika people as agents in their own labour mobility experiences, and the importance of Pasifika worldviews and transnational networks. These are considerations that dominant theories of diaspora negate in their analyses of Pasifika migrants.

Centering an indigenous perspective on Pasifika labour mobility also challenges the prevailing emphasis within much migration and diaspora literature on financial remittances as the primary measure of Pacific Islander labour migrations and networks. As shown here, the narratives recounted by Pasifika trans-Tasman migrants in Brisbane emphasise complex and multidimensional flows across transnational spaces, not only of people and money, but also of immaterial resources like skills, support, encouragement, care and community. The extended networks that underpin Pasifika notions of fämili and 'äiga highlight transnational labour mobility as a shared experience, incorporating individual, adult labour migrants, together with the family members who move with them, and extended families and communities in New Zealand, Tonga, Samoa and elsewhere. These extended family relations motivate and facilitate Pasifika labour mobility, and are at the heart of the 'good and happy life' that Pasifika seek.

40 Banivanua Mar, Decolonisation and the Pacific. 


\section{Bibliography}

Anae, M. 'Teu Le Va: Toward a Native Anthropology'. Pacific Studies 33, no. 2 \& 3 (August/December 2010): 222-40.

Arenofsky, J. Work-Life Balance: Health and Medical Issues Today. California: Greenwood Publishing Group Inc., 2017.

Banivanua Mar, Tracey. Decolonisation and the Pacific: Indigenous Globalisation and the Ends of Empire. New York: Cambridge University Press, 2016.

—. 'Shadowing Imperial Networks: Indigenous Mobility and Australia's Pacific Past'. Australian Historical Studies 46, no. 3 (2015): 340-55. doi.org/ 10.1080/1031461X.2015.1076012.

Bedford, R. 'Pasifika Migration: The New Zealand Story'. Around the Globe 6, no. 1 (2009): 37-44.

Brown, R. P. C. and A. M. Walker. Migrants and Their Remittances: Results of a Household Survey of Tongans and Western Samoans in Sydney. Sydney: Centre for South Pacific Studies, University of New South Wales, 1995.

Ehrenberg, Ronald G. and Robert Stewart Smith. Modern Labor Economics: Theory and Public Policy (13th ed.). New York: Routledge, 2018.

Fa'avae, David, Alison Jones and Linitā Manu'atu. 'Talanoa'i 'a e Talanoa: Talking about Talanoa'. AlterNative 12, no. 2 (2016): 138-50. doi.org/10.20507/ AlterNative.2016.12.2.3.

Faleolo, Ruth (Lute). 'Pasifika Trans-Tasman Migrant Perspectives of Well-Being in Australia and New Zealand'. Pacific Asia Inquiry 7, no. 1 (2016): 63-74.

—. 'Understanding Pasifika Migrant Behaviour and Perspectives of Well-Being in Brisbane through Material Cultural Adaptations'. 8th State of Australian Cities National Conference, 28-30 November 2017, Adelaide, South Australia. Australian Cities Research Network, 2018.

Fleming, Christopher M., Kifle Temesgen and Parvinder Kler. 'Immigrant Occupational Mobility in Australia'. Work, Employment and Society 30, no. 5 (2016): 876-89. doi.org/10.1177/0950017016631446.

Gershon, Ilana. 2007. 'Viewing Diasporas from the Pacific: What Pacific Ethnographies Offer Pacific Diaspora Studies'. The Contemporary Pacific 19, no. 2 (Fall 2007): 474-502. doi.org/10.1353/cp.2007.0050. 
Gray, Breda, Luigina Ciolfi, Aparecido Fabiano Pinatti de Carvalho, Anthony D'Andrea and Lisa Wixted. 'Post-Fordist Reconfigurations of Gender, Work and Life: Theory and Practice'. The British Journal of Sociology 68, no. 4 (2017): 620-42. doi.org/10.1111/1468-4446.12267.

Green, Alison E., Mary R. Power and Deannah M. Jang. 'Trans-Tasman Migration: New Zealanders' Explanations for Their Move'. New Zealand Geographer 64 (2008): 34-45. doi.org/10.1111/j.1745-7939.2008.00125.x.

Haig, R. New Zealand Department of Labour Report: Working across the Ditch New Zealanders Working in Australia. Department of Labour, New Zealand Government, 2010.

Halapua, S. 'Talanoa - Talking from the Heart'. SGI Quarterly 47 (2007): 9-10.

Hamer, Paul. "Unsophisticated and Unsuited": Australian Barriers to Pacific Islander Immigration from New Zealand'. Political Science 66, no. 2 (2014): 93-118. doi.org/10.1177/0032318714554495.

Hau'ofa, Epeli. 'Our Sea of Islands'. In A New Oceania: Rediscovering Our Sea of Islands edited by Epeli Hau'ofa, V. Naidu, and E. Waddell, 2-17. Suva: USP, Beake House, 1993.

Havea, Jione. Talanoa Ripples: Across Borders, Cultures, Disciplines. Albany, New Zealand: Massey University, 2010.

Ho, Elise, Graeme Hugo and Richard Bedford. 'Trans-Tasman Migration in Context: Recent Flows of New Zealanders Revisited'. People and Place 11, no. 4 (2003): 53-62.

Ka'ili, Tēvita O. Marking Indigeneity: The Tongan Art of Sociospatial Relations. Tuscon, AZ: The University of Arizona Press, 2017. doi.org/10.2307/j.ctt1 t89kr9.

Keck, Verena and Dominik Schieder. 'Contradictions and Complexities: Current Perspectives on Pacific Islander Mobilities'. Anthropological Forum, 25, no. 2 (2015), 115-30. doi.org/10.1080/00664677.2014.999644.

Latu, M. Talanoa: A Contribution to the Teaching and Learning of Tongan Primary School Children in New Zealand. MA thesis, Auckland University of Technology, Auckland, New Zealand, 2009.

Lilomaiava-Doktor, Sa'iliemanu. 'Beyond "Migration": Samoan Population Movement (Malaga) and the Geography of Social Space (Vā)'. The Contemporary Pacific 21, no. 1 (2009): 1-32. doi.org/10.1353/cp.0.0035. 
Māhina, H. O. 'Tā, Vā, and Moana: Temporality, Spatiality, and Indigeneity'. Pacific Studies, 33, no. 2 (2010): 168-202.

Mallon, Sean, Kolokesa Māhina-Tuai and Damon Salesa, eds. Tangata o le Moana: New Zealand and the People of the Pacific. Wellington: Te Papa Press, 2012.

Manuela, Sam and Chris G. Sibley. 'The Pacific Identity and Wellbeing Scale Revised (PIWBS-R)'. Cultural Diversity and Ethnic Minority Psychology 21, no. 1 (2015): 146-55. doi.org/10.1037/a0037536.

McGavin, Kirsten. 'Being Nesian: Pacific Islander Identity in Australia'. The Contemporary Pacific 26, no. 1 (Spring 2014): 95-154.

Meo-Sewabu, Litea and Wheturangi Walsh-Tapiata. 'Global Declaration and Village Discourses: Social Policy and Indigenous Well-Being'. AlterNative: An International Journal of Indigenous Peoples 8, no. 1 (2012): 305-17. doi.org/10.1177/117718011200800306.

Mila-Schaaf, K. 'Polycultural Capital and the Pasifika Second Generation: Negotiating Identities in Diasporic Spaces'. PhD thesis, Massey University, New Zealand, 2010.

Otsuka, S. Talanoa Research: Culturally Appropriate Research Design in Fiji. Proceedings of the Australian Association for Research in Education (AARE) 2005 International Education Research Conference, Melbourne, 2006. Accessed 14 March 2019, www.aare.edu.au/data/publications/2005/ ots05506.pdf.

Poot, Jacques. 'Trans-Tasman Migration, Transnationalism and Economic Development in Australasia'. Asian \& Pacific Migration Journal 19, no. 3 (2010): 319-42. doi.org/10.1177/011719681001900302.

Prescott, S. M. 'Using Talanoa in Pacific Business Research in New Zealand Experience with Tongan Entrepreneurs'. AlterNative: An International Journal of Indigenous Peoples 4, no. 1 (2008): 127-48. doi.org/10.1177/ 117718010800400111.

Ravulo, J. Pacific Communities in Australia. Sydney: University of Western Sydney, 2015.

Sailiata, K. G. 'The Samoan Cause: Colonialism, Culture, and the Rule Of Law'. $\mathrm{PhD}$ thesis, University of Michigan, 2014.

Salesa, Damon. 'Damon Salesa: Our Pacific Future Is Already Here'. E-Tangata, 10 December 2017, e-tangata.co.nz/news/damon-salesa-our-pacific-futureis-already-here. 
Smith, Linda Tuhiwai. Decolonizing Methodologies: Research and Indigenous Peoples (2nd ed.). London: Zed Books, 2012.

Tagata Pasifika. Second Migration of Pacific People. 3 part documentary series (presented by Sandra Kailahi). New Zealand: Tagata Pasifika, 2015.

Vaioleti, Timote. 'Talanoa Research Methodology: A Developing Position on Pacific Research'. Paper presented at the Pasifika Symposium on Pacific Research in Education, Hamilton, 2003.

Vaka'uta, Nasili. 'Tālanga: Theorizing a Tongan Mode of Interpretation'. AlterNative: An International Journal of Indigenous Peoples 5, no. 1 (2009): 126-39. doi.org/10.1177/117718010900500109.

Walrond, C. 'Kiwis Overseas'. Te Ara-the Encyclopedia of New Zealand, 2014, teara.govt.nz/en/kiwis-overseas. 
This text is taken from Labour Lines and Colonial Power: Indigenous and Pacific Islander Labour Mobility in Australia, edited by Victoria Stead and Jon Altman, published 2019 by ANU Press, The Australian National University, Canberra, Australia.

doi.org/10.22459/LLCP.2019.08 